\title{
Erratum to: Minimally Invasive Peroral Endoscopic Removal of a Regurgitated Giant Polysegmented Fibrovascular Polyp of the Esophagus
}

László Iván · Attila Torkos · Róbert Paczona •

Károly Szentpáli · József Jóri

Published online: 10 March 2010

(C) Springer Science+Business Media, LLC 2010

Erratum to: Dysphagia

DOI 10.1007/s00455-008-9165-0

This article has been retracted due to severe copyright violation by the authors.

The online version of the original article can be found under doi:10.1007/s00455-008-9165-0.

L. Iván $(\bowtie) \cdot$ A. Torkos · R. Paczona · J. Jóri

Department of Oto-Rhino-Laryngology and Head and Neck Surgery, University of Szeged, H-6725 Szeged, Hungary

e-mail: Ivan@ORL.SZOTE.U-Szeged.hu

K. Szentpáli

Department of Surgery, University of Szeged, Szeged, Hungary 